\title{
Oil Imports and the Fall of the Dollar
}

\author{
DOUGLAS R. MUDD and GEOFFREY E. WOOD
}

. . the cost of foreign oil to the U.S. economy $\$ 45$ billion this year, contributing to an estimated $\$ 30$ billion trade deficit - is weakening the dollar's value overseas and causing fresh concern about future U,S, economic stability. ${ }^{1}$

The above is one of many similar statements made during the past year reflecting the widely held belief that oil imports are the cause of the fall in the value of the dollar. Since imported oil in 1977 was the largest single component of total U.S. merchandise imports, the assertion is superficially plausible. Nowever, a slightly more wide-ranging look at the facts provides substantial evidence that this contention is incorrect.

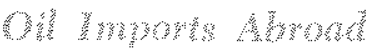

How much oil do other countries import? Certainly most Western countries import less oil than does the United States, but that is not surprising, since the United States is the largest economy in the West. In comparing oil imports across countries, these imports should be related to the size of each economy. Such a comparison reveals what fraction of the income from domestic production is being used to keep the country supplied with imported oil, thereby relating oil expenditures to what is actually available to be spent. ${ }^{2}$ The

1Harry B. Ellis, "Congress Imperils Oil-Cut Plar," Christian Science Monitor, October 11, 1977.

2This is the same kind of comparison one makes, for example, when determining whether a person's debts are too large. One looks not just at the debts, but at the debts relative to assets and income; only in that way can one calculate what the person can afford. results of relating expenditures on oil to the level of national income for the United States, Germany, and Japan are shown in Table I. It is immediately clear that the United States imported less oil as a percentage of its Gross National Product than either Germany or Japan in each year from 1970 through 1977. And yet the currencies of both Germany and Japan have appreciated, not only against the U.S. dollar, but also against almost every other currency in the world! (In 1977, the Deutsche mark rose by 11.3 percent against the dollar and by 7.0 percent against an average of currencies, while the yen rose by 20.8 percent against the dollar, and by 19.2 percent against an average of currencies.)

The simple relationship that is often suggested between large oil imports and a weak currency plainly is hard to reconcile with these facts. To see why this is so, it is necessary to examine the composition of the balance of payments in some detail.

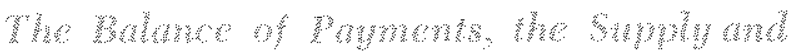

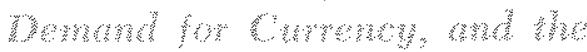

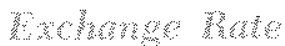

The balance-of-payments accounts of each country summarize its transactions with the rest of the world. These transactions can be subdivided in many ways. For present purposes it is most useful to separate them into three groups - the current account, which comprises the balance of trade and unilateral transfers, that is, gifts to foreigners; the capital account, which comprises capital movements for investment 


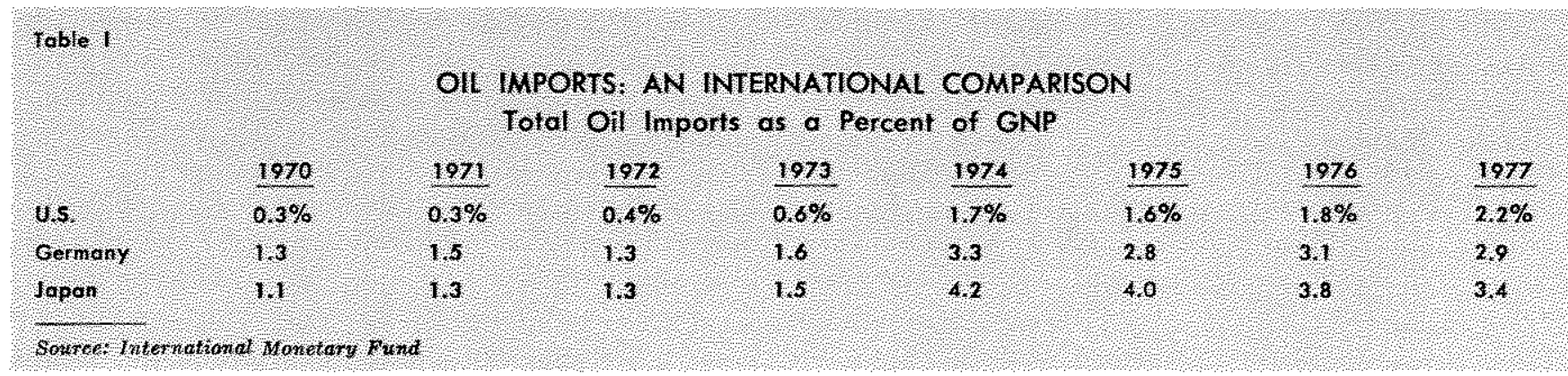

purposes by both the private sector and the government; and the intervention account, which comprises official movements of funds effected with the intention of influencing exchange rates.

The balance of trade includes all transactions in goods and services between a country and the rest of the world. All receipts from the sale of goods and services abroad are summed, all expenditures by a country's residents (including industry and govemment) on foreign goods and services are then subtracted, and the resulting total is the balance of trade. It can be positive (if receipts exceed expenditures), negative (if expenditures exceed receipts), or zero. Expenditures on imported oil appear in this part of the balance-of-payments accounts. In 1977, the United States was in deficit on its trade account with the rest of the world - that is, expenditures exceeded receipts - by some $\$ 10.5$ billion.

The United States must pay for this excess of expenditures over receipts in exactly the same way that an individual pays for expenditures which exceed receipts. The country can either sell its assets or borrow. These transactions are summarized in the capital account, which is subdivided between private and official capital movements. Capital movements for investment purposes are from one economy to either the private or the government sector of another economy. When someone buys securities from, or lends money to, a U.S. resident (including businesses and the U.S. Government) this transaction is called a capital infow. The converse transaction is called a capital outflow. The former is an inflow because it provides funds which can be spent, and the latter is an outflow because it is a way of disposing of funds.

Since different counties use different currencies, a country with a deficit on its trade account (like the United States last year) has spent more foreign cur-

Whe ffgure reflects the 5 une 22, 1978, change in the presentation of the balance-df-payments accounts. Unilateral transfers totalled $\$ 4.7$ billion in 1977 , resulting in a current acconnt deficit of \$15.2 billion. rency on foreign goods than it has received from foreigners. In other words, foreigners want less U.S. currency than the amount U.S. residents want to trade for foreign currency. The quantity of U.S. currency supplied (the amount U.S. residents want to spend) exceeds the quantity demanded (the amount foreigners want to buy) at the existing price of the currency on the foreign exchange market. ${ }^{4}$ When the quantity supplied exceeds the quantity demanded, price falls (the currency depreciates). This has the effect of decreasing the quantity supplied and increasing the quantity which is demanded; only when the two are equal - when the amount people want to supply equals the amount that people demand at the current price - is there no further change in price.

But while a trade deficit clearly does indicate that U.S. residents want to spend more dollars on foreign goods than foreigners wish to acquire to spend on U.S. goods, that does not mean that the total amount of U.S. dollars supplied on exchange markets exceeds the quantity demanded. This is because, as noted above, U.S. dollars can be both demanded and supplied for reasons other than trading in goods and services.

If foreigners wish to invest in the United States, they must acquire dollars. Similarly, if U.S. residents wish to invest outside the United States, they must aequire foreign currency. These capital movements provide both a source of supply and a source of demand for U.S. dollars on the foreign exchange market. It is quite possible, therefore, for a deficit in the trade accomt, which would lead by itself to an excess supply of dollars, to be fully offset by such capital llows." Thus, there is no necessary connection between a trade defict and a depreciating currency.

\footnotetext{
4The foreign exclange market is wher: currencies are traded. It is not a single location, but a network of traders all around the world.

It can also be more than offet, so that the United States woild either have an appreciating currency or an increase in its international reserves.
} 
What if, at the prevailing exchange rate, there is still an excess supply of a currency when both the trade account (plus unilateral transfers) and the capital account are considered? It is here that the official intervention account can become important. An excess supply of a currency can be removed by governments using other currencies to purchase the excess quantity, thus preventing its price from falling. This is what is called official intervention in foreign exchange markets. ${ }^{6}$

The important point to remember is that a deficit in the trade account does not necessarily cause a currency to depreciate. The excess supply of a currency which a trade deficit by itself implies can be offset by capital movements or official intervention to support the exchange rate, or both.

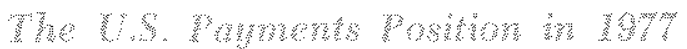

The United States ran a $\$ 35.2$ billion balance-ofpayments deficit in $1977,{ }^{7}$ Even after substantial official exchange market intervention by several countries to buy dollars, the foreign exchange value of the dollar fell. This implies that the quantity of U.S. dollars supplied on foreign exchange markets exceeded the quantity demanded; consequently, the price fell, reducing quantity supplied and increasing quantity demanded.

To repeat, recognizing that foreign currency values (or, in the presence of official intervention, reserve flows) are determined by the balance of supply and demand, just as is any other price, involves in turn recognizing that the U.S. dollar's value must have fallen because the dollar was in excess supply at the original exchange rate.

Now, every component of U.S. imports contributes to the supply of dollars on the foreign exchange market; hence, if one is to look at imports, there is no particular reason to look only at oil. But, more to the point, the above analysis of the balance of payments shows that any balance-of-payments position other than exact balance (on trade and capital accounts combined) implies an excess supply of one currency relative to those of the rest of the world. ${ }^{8}$

\footnotetext{
It can be seen from the above description that government capital movements for some reason other than to support the exchange rate have been classifed with private sector transactions.

$\tau$ "Balance of payments" is defined here as all international transactions excluding changes in official reserves.

8This point was made explicitly by David Hume in 1752 [" $\mathrm{Of}$ the Balance of Trade," Datid Hume: Writings on Economics,
}

If the U.S. money stock, for example, exceeds the amount people are willing to hold given the structure of interest rates and income levels - that is, there is an excess supply of money - then people will increase their spending as they attempt to reduce their holdings of money to desired levels. Spending on foreign goods, services, and securities, as well as domestic spending, will rise. As a result, the amount of dollars supplied on the foreign exchange market will increase. If the excess supply of money in the United States is greater than excess supplies of money in other countries, then the quantity of dollars supplied on the foreign exchange market will increase relative to quantities of other currencies supplied. Thus, the price of the dollar in terms of other currencies (its exchange rate) will come under downward pressure.

Eventually, if U.S. monetary growth does not continue to accelerate relative to any excess money growth abroad, movement toward equilibrium in both the domestic money market and the foreign exchange market will be accomplished as the U.S. price level rises and the foreign exchange value of the dollar declines. However, should the U.S. excess money supply continue increasing relative to that abroad, the foreign exchange value of the dollar will continue to fall; or, if there is intervention in the exchange market by central banks, a continuing balance-of-payments deficit will result."

So far it has been shown that a balance-of-payments deficit (or depreciating currency) must imply excess monetary growth (relative to any excess money growth there may be abroad) in the country whose exchange rate is depreciating. Can oil imports cause such an excess?

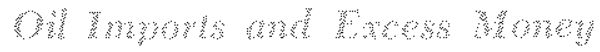

The comparison between the United States and other countries made at the beginning of this article shows that oil imports do not have to cause excess monetary expansion, and hence an excess supply of dollars on the foreign exchange market. (The

ed. Eugene Rotwein (Madison: University of Wisconsin Press, 1970), pp, 60-77]. In this century, it is associated particularly with the work of Harry G. Johrson, for example, "The Monetary Approach to Balance-of-Payments Theory," in. The Monetary Approach to the Balance of Payments, ed. Jacob A. Frenkel and Harry G. Johnson (London: George Allen and Unwin Ltd, 1976), pp. 147-67.

If the excess money growth is not restrained, interest rates will rise as inflation accelerates. If on the other hand the excess money growth is held back, then the dollar will stop falling and there will be no upward trend in interest rates. 
Deutsche mark and yen have certainly not been depreciating on the foreign exchange market.) But it is useful also to look at the actual data on oil imports into the United States, and how the revenue which accrued to non-U.S. residents as a result was spent.

The value of oil imports has indeed accounted for a substantial proportion of merchandise imports since the price increases of 1974. In 1977, for example, the value of oil imports totalled $\$ 45$ billion, amounting to 30 percent of total U.S. merchandise imports. But the U.S. balance-of-trade deficit with oil-exporting countries was only $\$ 16.9$ billion in $1977 .^{10}$ That it was substantially less than U.S. expenditures on oil shows that the oil producers spent considerable amounts on U.S. goods and services. Furthermore, oilexporting countries net purchases of U.S. corporate stocks and bonds and U.S. Government securities were about $\$ 7$ billion during 1977.11 Oil exporting countries holdings of U.S. commercial bank deposits also increased by about $\$ 400$ million during the past year. These capital inflows offset about 45 percent of the 1977 U.S. balance-of-trade deficit with oil exporting countries. $^{12}$

Reduction (or elimination) of oil imports certainly would not produce an equal reduction in (or eliminate) the current U.S. balance-of-trade deficit. To the extent that dollars earned from oil exports to the United States are used to purchase U.S. goods, services, and securities, the balance-of-payments effects of rising oil imports by the United States are offset. To reduce the U.S. balance of-trade deficit by reducing the amount of oll imports would require oilexporting countries to maintain both their current purchases of U.S. goods and their current rate of investment in the United States, despite a fall in their

10This figtre does not reflect the presentational change in the balance-of-payments accounts of June 22,1978 . If it were possible to make this presentational change, the above U.S. bilateral trade deficit with the oil exporting countries would be reduced sharply.

11Direct foreign exchange market intervention by the members of OPEC is negligible. Thes, purchases of US. Government securities by OPEC governments presumably reflect investment decisions, rather than the results of exchange market intervention.

${ }_{12} \mathrm{~A}$ detailed account of U.S. transactions with OPEC can be found in Christopher L. Bach, "OPEC Transactions in the U.S. International Accounts," Surtey of Current Business (April 1978), pp. 21-32. It shonld be noted that had prices risen as they have done in the United States without a fall in the foreign exchange value of the dollar, OPEC members would probably have spent less in the United States than they actually did, since U.S. goods and capital assets would have been more expensive, relative to those in the rest of the world, than they now are. earnings. It is hard to imagine that countries would continue to both spend and invest as they now do when faced with a substantial drop in income. Reducing U.S. oil imports would therefore almost certainly reduce both U.S. exports and capital inflows into the United States. ${ }^{13}$

Furthermore, consider what would happen to other components of U.S. expenditures if oil imports were suddenly cut off and there were no cutback to excess money growth in the United States. U.S. residents would wish to spend the money that was previously spent on oil. Some of it would be spent on other imports. Some would be spent on goods that had previously been exported. There would be increased demand for goods which had been previously produced and consumed domestically. This would divert to the production of these goods resources previously used elsewhere, and would thereby further reduce U.S. exports and increase U.S. imports. Some of the money would be used to purchase capital assets abroad. And, of course, some of the money would be used to purchase capital assets in the United States, which would raise their price and reduce the rate of interest, thereby, in turn, reducing the inflow of capital from abroad.

A cutback on oil imports without a cutback on excess money growth in the United States (relative to any excess money growth there may be abroad) could not have a marked effect on the U.S. balance of payments or the foreign exchange value of the dollar. And, of course, if U.S. money growth were cut back sufficiently to eliminate the excess supply of dollars on the foreign exchange market, then the slide in the dollar's foreign exchange value would end without any misguided and welfare-reducing attacks on individual components of U.S. foreign trade. ${ }^{14}$

\footnotetext{
13It nay perhaps be argued that the U.S. "oil deficit" has produced expectations of a falling U.S. dollar, and hence a flight from the dollar to other currencies, but this cannot be reconciled with the strength of the Deutsche mark and Japanese yen - Gemany and Japan have larger "oil deficits" relative to the size of their economies, than does the United States. The argument that the "oil deficit" has produced the fall of the dollar through its effect on expectations is therefore not persuasive.

${ }^{14}$ The oil price increases would have had a minor effect on the value of the U.S. dollar to the extent that the price increases reduced real income in the U.S. See Robert $H$. Rasche and John A. Tatom, "The Effects of the New Fnergy Regime on Economic Capacity, Production, and Prices, this Review (May 1977), pP. 2-12. This fall in real income would reduce the demand for money, and thus produce an excess supply of dollars without any change in the quantity supplied. But there are two reasons why oil imports cannot, via that route, be blamed for the fall in the
} 


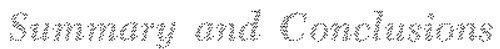

The increasing value of U.S. oil imports has not "caused" the U.S. balance-of-payments deficit and the declining foreign exchange value of the dollar. Oilexporting countries purchases of U.S. goods and serv-

value of the dollar. First, when that excess supply had been disposed of, the dollar would stop falling, and there would not be the sustained slide we have seen since early 1977.

Second, the Federal Reserve, should it have chosen to do so, could have reduced the money stock so as to eliminate that excess. ices and their investment in the United States have offset, to a large extent, the balance-of-payments effects of rising oil imports. Thus, policies directed toward reducing oil imports will have little effect on the current trend of the dollar's declining foreign exchange value. Further, the primary determinant of the 1976-77 deficits was not "an insatiable appetite" for foreign oil. Balance-of-payments deficits and weak currencies are monetary phenomena, resulting from excess money growth in the country with the deficit relative to money growth abroad.

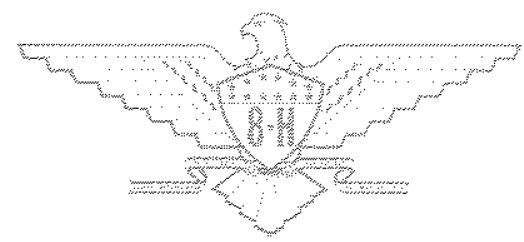

